\title{
The Kansas Offender Registration Act: Where's the Constitutional Limit?
}

\author{
Lindsay Strong*
}

\section{INTRODUCTION}

Joe, the defendant in this hypothetical case, was charged with aggravated burglary, aggravated robbery, theft, and criminal possession of a firearm. These charges stemmed from his involvement in a forcible entry into an apartment. As Joe entered into the apartment, he demanded money from its occupants. While demanding money, Joe was holding what was described as a "skinny weapon" that had a pistol grip in the front and rear. When the police finally arrived on the scene, however, no weapon was found. Nor was any weapon found when Joe was later apprehended.

Joe plead guilty to a charge of aggravated burglary and a reduced charge of robbery at his plea hearing. In exchange to pleading these counts, the State agreed to drop the other charges against Joe. Notably, none of the charges Joe pleaded to alleged he used a "deadly weapon" during the commission of those crimes. The district court accepted Joe's pleas, but also made a finding that a firearm was used in the commission of the crime.

If Joe were a resident of a state such as Alaska, he would most likely be sentenced to serve concurrent sentences. These sentences would roughly amount to a little under five years of incarceration. Joe's sentence would be unaffected by the judge's finding of Joe being in possession of a firearm because doing so would violate Joe's Apprendi ${ }^{1}$ rights. $^{2}$

\footnotetext{
* J.D. Candidate, 2018, University of Kansas School of Law. I thank Professor Thomas Stacy for his knowledge and insight provided throughout the writing process. I also thank Mathew Petersen, Mackenzie Sheehy, and the staff of the Kansas Law Review for their review of this article along with their hard work and dedication to this publication.

1. Under Apprendi v. New Jersey, 530 U.S. 466, 466 (2000), any fact that increases either the maximum penalty the law permits, or the minimum penalty the law requires, must be found by a jury beyond a reasonable doubt.

2. This introductory hypothetical is modeled after the facts set forth in State v. Huey, 399 P.3d 211 (2017). A petition for certiorari to the United States Supreme Court has been filed and has been placed on the Court's docket for possible hearing.
} 
In this hypothetical, however, Joe is a resident of Kansas. Joe would be sentenced to a length of incarceration comparable to five years. But because the judge found that Joe was in possession of a firearm, Joe would also be subject to registering under the Kansas Offender Registry Act (KORA) for a minimum of fifteen years. ${ }^{3}$ The finding of Joe being in possession of a firearm while committing his offenses would require Joe to register in person at least four times a year paying a fee each time. Joe's Apprendi rights would not be violated, however, because the Kansas Supreme Court has held that KORA constitutes a civil regulatory scheme rather than criminal punishment. ${ }^{4}$

The Kansas Supreme Court's decision upholding KORA as a civil regulatory scheme relies on the United States Supreme Court decision in Smith v. Doe. ${ }^{5}$ In Smith, the United States Supreme Court upheld the Alaska Sex Offender Registration Act ("ASORA") as a civil regulatory scheme rather than a form of punishment. ${ }^{6}$ In deciding that KORA was a civil regulatory scheme rather than punishment, the Kansas Supreme Court stated the question presented was whether "there are convincing reasons to believe that the United States Supreme Court . . . would view the current version of KORA differently than it viewed [the Alaska law] in 2003 when it decided Smith[?]"7 Ultimately, the Kansas Supreme Court held that if the United States Supreme Court were to view KORA as it did in 2003 when it decided Smith, the Court would decide KORA was not punitive. ${ }^{8}$

If the Supreme Court of the United States were to view KORA today, however, the Court should distinguish KORA from ASORA and hold that KORA is punitive for two main reasons: (1) empirical evidence regarding recidivism and the effect of registries has changed since its decision in Smith; and (2) KORA sweeps more broadly than ASORA by including all violent offenders and drug offenders in its registry. In light of the possibility of the United States Supreme Court granting certiorari

3. KAN. STAT. ANN. § 22-4906(a)(1)(N) (West 2017 \& Supp.) (requiring registration for a period of fifteen years for anyone convicted "of any person felony and the court makes a finding on the record that a deadly weapon was used in the commission of such person felony.").

4. See State v. Petersen-Beard, 377 P.3d 1127, 1130-31 (Kan.), cert. denied, Petersen-Beard v. State, 137 S. Ct. 226, 226 (2016); see also State v. Villa, No. 112,107, 2017 WL 3583729 at *1 (Kan. Aug. 18, 2017) (refusing to review whether KORA constitutes a punishment because the challenge was raised for the first time on appeal).

5. Petersen-Beard, 377 P.3d at 1129-30.

6. Smith v. Doe, 538 U.S. 84,84 (2003).

7. Id. at 1144

8. Id. 
in Huey v. Kansas, ${ }^{9}$ this Comment distinguishes KORA from ASORA and argues that the United States Supreme Court should hold that KORA constitutes punishment under the United States Constitution.

Section II of this Comment first introduces the history of Kansas offender registries and today's modern version: KORA. The section then examines the U.S. Supreme Court's decision in Smith v. Doe upholding ASORA. Finally, the section provides an overview of the Kansas Supreme Court's decision holding that KORA is a civil form of regulation rather than criminal punishment.

Next, Section III analyzes the differences between KORA and ASORA. First, KORA will be distinguished from ASORA by applying modern empirical evidence under the Mendoza-Martinez factors. Second, KORA will be distinguished from ASORA because KORA sweeps more broadly, i.e., KORA includes more offenses subject to registry than ASORA. This Comment then concludes that because the provisions of KORA and ASORA can be distinguished, the U.S. Supreme Court should distinguish KORA from ASORA and hold that KORA constitutes punishment under the United States Constitution.

\section{BACKGROUND}

Whether legislation is civil or punitive determines the rights and obligations afforded to defendants by the court. When legislation is characterized as punitive, courts will be obligated to provide the necessary criminal procedure protections as demanded by the Constitution. Such procedures include due process, equal protection, privilege against self-incrimination, cruel and unusual punishment, right to privacy, double jeopardy, ex post facto, right to jury trial, or Apprendi rights. ${ }^{10}$ In contrast, laws that are considered civil or regulatory in nature will not be subject to such constitutional demands. ${ }^{11}$

Concluding that KORA is civil rather than criminal punishment eliminates any constitutional challenges to the statute. Such constitutional rights are only ascertainable if the law in question is deemed criminal or imposes "punishment" for constitutional purposes. ${ }^{12}$

9. State v. Huey, 399 P.3d 211 (Kan. 2017), petition for cert. filed, case no. 17-7282 (U.S. Jan. 8, 2018).

10. Catherine L. Carpenter \& Amy E. Beverlin, The Evolution of Unconstitutionality in Sex Offender Registration Laws, 63 HASTINGS L.J. 1071, 1101 (2012).

11. Id.

12. Stephen R. McAllister, The Constitutionality of Kansas Laws Targeting Sex Offenders, 36 WASHBURN L.J. 419, 437 (1997). 
As long as the requirements are sufficiently tailored to meet the nonpunitive purpose of the Act, it will remain constitutional. ${ }^{13}$ Defendants must adhere to the registration requirements set forth in the Act without any recourse under current precedent.

\section{A. K.S.A. $\S 22-4901$}

The first Kansas statute governing the registration of sexual offenders, known as the Habitual Sex Offender Registration Act (HSORA), was enacted in $1993 .{ }^{14}$ At the outset of this Act, only twiceconvicted or "habitual" sex offenders were required to register. ${ }^{15}$ Within thirty days after a habitual sex offender arrived in a county where they intended to reside for longer than thirty days, the offender was required to register specific information with the county sheriff. ${ }^{16}$

The offender was required to provide their name, date of birth, details of their conviction, his photograph, fingerprints and social security number. ${ }^{17}$ Failure to provide the required information within thirty days was punished as a class A nonperson misdemeanor. ${ }^{18}$ An offender was required to register for a period of ten years following their release from probation or parole. ${ }^{19}$ Notably, the information provided by the offender was not made public and was not subject to the Kansas Open Records Act. ${ }^{20}$ The information could only be accessed by law enforcement officials or individuals specifically authorized by law. ${ }^{21}$

Further, under HSORA, an offender could apply to be relieved of the duty to register at any time by filing for a hearing in the county court of his residence. ${ }^{22}$ If a court found by a preponderance of the evidence that the offender had been rehabilitated, the court was required to relieve the offender of the duty to register. ${ }^{23}$

13. See Catherine L. Carpenter, Legislative Epidemics: A Cautionary Tale of Criminal Laws that Have Swept the Country, 58 BUFF. L. REV. 1, 42-43 (2010) (citing Kansas v. Hendricks, 521 U.S. 346 (1997)).

14. Habitual Sex Offender Registration Act, ch. 253, § 17, 1993 Kan. Sess. Laws 253.

15. Shawn P. Yancy, The History and Future of Offender Registration in Kansas, J. KAN. B.A., Oct. 2012, at 34, 35 .

16. $\S 20(a), 1993$ Kan. Sess. Laws 253 (current version at KAN. STAT. ANN. § 22-4904).

17. Id. § 23(a) (current version at KAN. STAT. ANN. § 22-4907(a)).

18. Id. $\S 19$ (current version at KAN. STAT. ANN. § 22-4903).

19. Id. § 22(a) (current version at KAN. STAT. ANN. § 22-4903).

20. Id. § 25 (current version at KAN. STAT. ANN. § 22-4909).

21. Id.

22. Id. § 24 (current version at KAN. STAT. ANN. § 22-4908).

23. Id. 
One year after its reenactment, the law was transformed into the Sex Offender Registration Act (SORA) and required first-time sex offenders to register. ${ }^{24}$ The new Act was prompted by the brutal assault and killing of a young woman named Stephanie Schmidt. ${ }^{25}$ At the time Schmidt's assailant committed the crime, the perpetrator was on parole from convictions of rape and aggravated sodomy. ${ }^{26}$ The public outrage, fueled by the publicity of the crime, resulted in the expansion of the prior Act by making registration applicable to first time offenders. ${ }^{27}$ The argument that sex offenders presented an increased recidivism rate gained credence as the public fear grew. ${ }^{28}$

Under SORA, an offender convicted of a sexually motivated crime, ranging from stealing a woman's underwear during a burglary to rape, ${ }^{29}$ was required to register for a ten-year period. ${ }^{30}$ An offender convicted for a second time of a sexually motivated crime was required to register for life. ${ }^{31}$ Such registration was made open and available to the public at the local sheriff's office or through the Kansas Open Records Act. ${ }^{32}$ The time period for registration after relocation was shortened from 30 days to 15 days. $^{33}$

The Act was amended in 1996 to require offenders to provide additional information about the crime and themselves, including the sex and age of the victim, the offender's address, the offender's DNA exemplars, the offender's driver's license and vehicle information, the offender's occupation and name of his employer, and any identifying characteristics of the offender such as race, hair and eye color, scars and blood type. ${ }^{34}$ For the first time, the offender's home address and place of employment were made available to the public.

\footnotetext{
24. Yancy, supra note 15 , at 35.

25. Rick Kittel, K.S.A. 22-4901 et seq.-Offender Registration in Kansas, J. KAN. B.A., JuneJuly 2000, at 28, 29.

26. Id.; see also State v. Gideon, 894 P.2d 850, 855 (Kan. 1995).

27. Kittel, supra note 25 , at 29 .

28. Id. at 29 n.12.

29. See State v. Patterson, 963 P.2d 436, 437 (Kan. Ct. App. 1998), rev. denied (Sept 14, 1998).

30. Sex Offender Registration Act, ch. 107, § 5, 1994 Kan. Sess. Laws 107 (current version at KAN. STAT. ANN. § 22-4906(a)).

31. Id. § 5 (current version at KAN. STAT. ANN. § 22-4906(c)).

32. Id. § 7 (current version at KAN. StAT. ANN. § 22-4909). The Kansas Open Records Act is found at KAN. STAT. ANN. § 45-215-54 (2008).

33. Id. §3(a) (current version at KAN. STAT. ANN. § 22-4904).

34. Sex Offender Registration Act, ch. 224, § 5, 1996 Kan. Sess. Laws 224 (current version at KAN. STAT. ANN. § 22-4907).
} 
In 1997, the Kansas Legislature renamed the Act the Kansas Offender Registration Act (KORA) and slowly started to expand the reach of registration. ${ }^{35}$ The Act was revised to reach beyond sex offenders to include certain violent crimes and personal offenses against victims under the age of eighteen. ${ }^{36}$ The category of sex offenders included those convicted of certain listed sex offenses, those convicted of comparable offenses from other jurisdictions, those convicted of an attempt, conspiracy or solicitation to commit one of the listed sex offenses, or those convicted of sexually motivated crimes. ${ }^{37}$ Violent offenders consisted of those convicted of a homicide, those convicted of comparable offenses from other jurisdictions, or those convicted of an attempt, conspiracy or solicitation to commit a homicide. ${ }^{38}$

Under KORA, offenders' ability to petition the court for relief from registration was seriously limited. Only those who had already registered for a period of ten years for each conviction requiring registration were eligible to seek relief from the registration requirement. ${ }^{39}$ Further, upon petitioning for relief, the offender was required to provide evidence documenting any treatment for a mental illness or personality disorder. ${ }^{40}$

In 1999, the Act was amended to create a category called "aggravated offenses" for which an offender was required to register for a lifetime, even if it was their first and only offense. ${ }^{41}$ "Aggravated offenses" were defined as a sexual act, or any attempt, solicitation or conspiracy to commit a sexual act of penetration with a victim of any age through the use of force or threat of violence, or a sexual act or any attempt, solicitation or conspiracy to commit a sexual act of penetration with a victim less than fourteen years of age. ${ }^{42}$

The penalty for violating the Act was raised to a severity level 10, nonperson felony offense. ${ }^{43}$ At this time, the Act required registration within ten days of relocation to another county. ${ }^{44}$ Relief from offender

\footnotetext{
35. Yancy, supra note 15, at 35.

36. Id.

37. Kansas Offender Registration Act, ch. 181, § 8, 1997 Kan. Sess. Laws 181 (current version at KAN. STAT. ANN. § 22-4902(b)-(c)).

38. Id. § 8 (current version at KAN. STAT. ANN. § 22-4902(e)).

39. Id. § 13 (current version at KAN. STAT. ANN. § 22-4902(e)).

40. Id.

41. Kansas Offender Registration Act, ch. 164, § 33, 1999 Kan. Sess. Laws 164 (current version at KAN. STAT. ANN. § 22-4906(d)).

42. Id. $\S 29$ (current version at KAN. STAT. ANN. § 22-4906(d)).

43. Id. $\S 30$ (current version at KAN. STAT. ANN. § 22-4903).

44. Id. $\S 10$ (current version at KAN. STAT. ANN. § 22-4904).
} 
registration was further restricted to only first time offenders who had not been convicted of an aggravated offense, and had registered for a period of at least ten years under the Act. ${ }^{45}$

In 2001, the Act added the requirement of sexually violent predators and new permanent residents of Kansas who were offenders required to register in their original jurisdiction to register. ${ }^{46}$ In 2002, the Act was amended to require juvenile sex offenders to register until they reached the age of eighteen. ${ }^{47}$ In 2005 , provisions were added to notify schools and childcare facilities if offenders were registered near their facilities. ${ }^{48}$ The publisher was required to distinguish between sex offenders and violent or drug offenders. ${ }^{49}$

In 2006, failing to register became a level 5, person felony. ${ }^{50}$ Failing to register for more than 30 days created a new offense and subsequent offenses were committed for each thirty-day period thereafter. ${ }^{51}$ In 2007, the Legislature added three drug offenses - but provided an exception if the offender's possession or manufacture was for personal use. ${ }^{52}$

In 2011, the personal use exception was removed. ${ }^{53}$ KORA now mandates the registration of not only sex offenders upon conviction, but violent offenders and drug offenders as well. ${ }^{54}$ Under KORA, such offenders may be subject to registration for fifteen-years, ${ }^{55}$ twenty-five years, ${ }^{56}$ or life $^{57}$ depending on the offense committed. The informal

\footnotetext{
45. Id. § 34 (current version at KAN. STAT. ANN. § 22-4908).

46. Kansas Offender Registration Act, ch. 208, § 11, 2001 Kan. Sess. Laws 208 (current version at KAN. STAT. ANN. § 22-4904).

47. Yancy, supra note 15 , at 35.

48. Kansas Offender Registration Act, ch. 202, § 2, 2005 Kan. Sess. Laws 202.

49. Id.

50. Kansas Offender Registration Act, ch. 212, § 20, 2006 Kan. Sess. Laws 212 (current version at KAN. STAT. ANN. § 22-4903).

51. Id.

52. Yancy, supra note 15 , at 35 .

53. Id.

54. KAN. StAT. ANN. § 22-4906 (West 2017 \& Supp.).

55. Id. § 22-4906(a)(1)(A)-(R). Such convictions subjected to fifteen-years of registry include sexual battery, adultery, promoting the sale of sexual relations, patronizing a prostitute, lewd and lascivious behavior, capital murder, murder in the first degree, murder in the second degree, voluntary manslaughter, involuntary manslaughter, criminal restraint, unlawful manufacture or attempting such of any controlled substance, possession of ephedrine, pseudoephedrine, red phosphorus, lithium metal, sodium metal, iodine, anhydrous ammonia, pressurized ammonia or phenylpropanolamine, or their salts, isomers or salts of isomers with the intent to use the product to manufacture a controlled substance, any attempt, conspiracy or criminal solicitation, and conviction of any person felony and the court makes a finding on the record that a deadly weapon was used in the commission of such personal felony. Id.

56. Id. § 22-4906(b)(1)(A)-(J). Such convictions subjected to twenty-five years of registry include criminal sodomy, indecent solicitation of a child, electronic solicitation, aggravated incest,
} 
reporting period was lowered to three days to comply with federal mandate established in the Adam Walsh Child Protection and Safety Act of $2006 .^{58}$

In 2011, the information required to be reported by offenders was expanded and now includes: 1) name and aliases; 2) date and city, state and country of birth and any aliases; 3 ) title and statute number of each offense, date of each conviction and court case numbers; 4) city, county, state or country of conviction; 5) sex and date of birth of each victim; 6) current residential address, anticipated future residence and any temporary lodging information; 7) all telephone numbers at which the offender may be contacted; 8) Social Security number, and all alias Social Security numbers; 9) identifying characteristics, such as race, ethnicity, skin tone, sex, age, height, weight, hair and eye color, scars, tattoos and blood type; 10) occupation and name, address or addresses and telephone number of employer(s) and any anticipated employer(s); 11) all current driver's licenses or identification cards, including a photocopy of all such driver's licenses or identification cards and their numbers, states or issuance and expiration dates; 12) all vehicle information including license plate number, registration number and description of any vehicle owned or driven by the offender; 13) license plate number, registration number or description of any aircraft or watercraft owned or operated by the offender; 14) all professional licenses, designations and certifications; 15) documentation of any treatment received for mental abnormality, illness or personality disorder of the offender; 16) photograph(s); 17) fingerprints and palm prints; 18) any and all schools attended or expected to be attended and locations and telephone numbers; 19) any and all email addresses, any and all online identities used on the internet or any information relating to any membership in any online social networks; 20) all travel and immigration documents; and 21) name and telephone number of the offender's probation, parole or community corrections officer. ${ }^{59}$

\footnotetext{
indecent liberties with a child, unlawful sexual relations, sexual exploitation of a child, aggravated sexual battery, promoting prostitution, and any attempt, conspiracy, or criminal solicitation. Id.

57. An offender subsequently convicted of a second offense requiring registration will result in lifetime registration. Id. $\S 22-4906(\mathrm{c})$. Convictions subjected to lifetime registration include rape, aggravated indecent solicitation of a child, aggravated indecent liberties with a child, criminal sodomy, aggravated criminal sodomy, aggravated human trafficking, sexual exploitation of a child, promoting prostitution, kidnapping, aggravated kidnapping, commercial sexual exploitation of a child, or any attempt, conspiracy or criminal solicitation. Id. § 22-4906(d)(1)-(12).

58. Id. §5 (current version at KAN. STAT. ANN. § 22-4905(b)).

59. Id. § 7 (current version at KAN. STAT. ANN. § 22-4907).
} 
A graduated punishment scheme was enacted in 2011 whereby an initial failure to register is a level 6, person felony; a second failure is a level 5, person felony; and a third or subsequent failure to register is a level 3, person felony. ${ }^{60}$ An aggravated failure to register, a failure lasting more than 180 consecutive days, is a level 3, person felony. ${ }^{61}$ Every 180 days of failing to register constitutes a new and separate offense. ${ }^{62}$

\section{B. Civil Regulatory Scheme vs. Punitive: The United States Supreme Court's Solution}

While some legislation can be clearly defined as a regulatory scheme or criminal punishment, legislation regarding offender registries blurs the line. The Supreme Court sought to clarify the distinction between civil and criminal legislation in regard to sex offender laws in Smith v. Doe. ${ }^{63}$ In Smith, the petitioners challenged the constitutionality of the Alaska Sex Offender Registration Act (ASORA) under the Ex Post Facto Clause $^{64}$ of the United States Constitution. The Ex Post Facto Clause specifically prohibits retroactive application of laws that demand greater punishment than the law at the time the offense was committed. ${ }^{65}$ The petitioners argued that ASORA violated this clause because even though they were convicted of their crimes before the passage of ASORA, the Act required their registration. ${ }^{66}$ In order to successfully make an ex post facto violation claim, however, petitioners had to prove that ASORA was criminal punishment. ${ }^{67}$ Since precedent held that sex offender registries were civil regulatory schemes, the Smith Court had to analyze the specific requirements set forth in ASORA. ${ }^{68}$

Under ASORA, offenders convicted prior to and after the establishment of the Act were required to register. ${ }^{69}$ ASORA had two components: (1) a registration requirement for offenders; and (2) a notification system. ${ }^{70}$ Offenders who were required to register under

\footnotetext{
60. Id. $\S 3$ (current version at KAN. STAT. ANN. $\S 22-4903(\mathrm{c})$ ).

61. Id. (current version at KAN. STAT. ANN. § 22-4903(c)(2)).

62. Id. (current version at KAN. STAT. ANN. § 22-4903(b)).

63. See Smith v. Doe, 538 U.S. 84, 84 (2003).

64. Id.

65. U.S. Const. art. I, $\S 10$.

66. Smith, 538 U.S. at 91-92 (2003)

67. Id.

68. Smith, 538 U.S. at 89-91.

69. Id. at 89 .

70. Id. at 90 .
} 
ASORA included those convicted of sex offenses and child kidnapping. ${ }^{71}$ Under ASORA, offenders were subject to either a registration length of fifteen years or reporting quarterly for life. ${ }^{72}$ In order to report in compliance with ASORA, offenders were required to provide written verification of the offender's address and update any changes to the information required by registration. ${ }^{73}$ Such information included the name of the sex offender, aliases, identifying features, photograph, fingerprints, address, place of employment, date of birth, conviction information, driver's license number, information about vehicles to which he has access, and post-conviction treatment history. ${ }^{74}$ This information was then was given to the Alaska Department of Public Safety to make public. $^{75}$ While ASORA did not specify how the information was to be made public, Alaska chose to make the information available on the internet. ${ }^{76}$

The Smith Court applied its "intent-effects" test to determine whether the Alaska Legislature intended to establish a civil regulatory scheme or criminal punishment. If the legislature intended to impose punishmentthe inquiry would end there. However, if the legislature intended to enact a civil regulatory scheme, then the Court would proceed to evaluate the statute to determine whether the effects of the statute were so punitive that it overrides the legislature's intention for it to be civil. ${ }^{77}$ In order to determine whether a statute had overridden the legislature's intent to create a civil regulatory scheme, the Court applied the factor test developed from their decision in Kennedy v. Mendoza-Martinez ${ }^{78}$

The Court first analyzed ASORA under the "intent-effects" test by: "(1) determining whether the legislature's intention was to enact a... regulatory scheme that is civil and nonpunitive and, if so, (2) examin[ing] whether the statutory scheme is so punitive either in purpose

71. Alaska Stat. ANN. $§ 12.63 .010$ (West $2007 \&$ Supp. 2014).

72. Alaska Stat. ANN. § 12.63.020(a)(1)-(2) (West 2007 \& Supp. 2014). Offenders convicted of non-aggravated sex offense or a single child kidnapping were subject to annual reporting for fifteen years. Id. $\S 12.63 .020$ (a)(2).

73. AlASKA STAT. ANN. § 12.63.010(d)(1)-(2) (West 2007 \& Supp. 2014).

74. Id. § 12.63.010(b)(1)(A)-(I).

75. Alaska Stat. AnN. § 18.65.087(a) (West $2007 \&$ Supp. 2014).

76. Smith v. Doe, 538 U.S. 84, 91 (2003).

77. Id. at 92 .

78. Kennedy v. Mendoza-Martinez, 372 U.S. 144, 168-69 (1963). In Mendoza-Martinez, the Court held that the deprivation of nationality as a result of remaining outside the country for purposes of evading military service was a form of punishment and therefore unconstitutional. Id. at 186. While the Mendoza-Martinez Court did not decide the issue of the constitutionality of sex offender registries, the Court did establish a seven-factor test to distinguish whether a statute is regulatory or punitive. Id. at 168-69. 
or effect as to negate [the State's] intention to deem it civil.," 79 The Court based its conclusion on the legislature's expressed objective of ASORA in the statute itself. ${ }^{80}$ In ASORA, the Alaska Legislature stated that the Legislature had found sex offenders to "pose a high risk of reoffending" warranting a set of laws to protect the public from sex offenders. ${ }^{81}$ This express objective, combined with the fact that ASORA was contained in the State's Health, Safety, and Housing Code, led the Court to conclude that the intent of the Alaska Legislature was to create a civil regulatory scheme to promote public safety. ${ }^{82}$

To determine whether the effects of ASORA were punitive enough to override the Alaska Legislature's intent of creating a civil regulatory scheme, the effects of the legislation were then analyzed by the Mendoza-Martinez factors. ${ }^{83}$ The Mendoza-Martinez factors inquire whether the regulatory scheme: (1) "has been regarded in our history and traditions as a punishment;" (2) "imposes an affirmative disability or restraint;" (3) "promotes the traditional aims of punishment;" (4) "has a rational connection to a nonpunitive purpose;" or (5) "is excessive with respect to its purpose." ${ }^{\text {, }}$

First, the Smith Court held that ASORA and sex offender registries alike were not punitive because registries have not been embedded into our society as traditional forms of punishment. ${ }^{85}$ The Court limited the definition of "traditional punishments" to only embody "colonial punishments" such as banishment, shaming, and branding. ${ }^{86}$ Sex offender registries, however, were distinguished from these types of traditional punishments; the Smith Court stated that while some forms of colonial punishments such as shaming were meant to inflict public

79. Doe v. Thompson, 373 P.3d 750, 761-62 (Kan.) overruled by State v. Petersen-Beard, 377 P.3d 1127 (Kan. 2016) (quoting Smith, 538 U.S. at 92) (internal quotation marks omitted).

80. See Smith, 538 U.S. at 92-95.

81. Id. at 93 (citing Alaska Sex Offender Registration Act, ch. 41, § 1, 1994 Alaska Sess. Laws 41 (current version at ALASKA STAT. ANN. 12.63.010 (West 2007 \& Supp.))).

82. Id. at $92-97$.

83. Id. at 97.

84. Id. at 97. The Supreme Court dismissed two of the seven factors - "whether the regulation comes into play only on a finding of scienter and whether the behavior to which is applies is already a crime ...." Id. at 105. The Court declared these factors had "little weight" given that they inquired whether past conduct, i.e. a crime, had been committed. Id. Committing a crime is the necessary beginning point of registration, and the "obligations the statute imposes are the responsibility of registration, a duty not predicated upon some present or repeated violation." Id.

85. Id. at 97 .

86. Id. at 97-98. See also Andrea E. Yang, Historical Criminal Punishments, Punitive Aims and Un- "Civil" Post-Custody Sanctions on Sex Offenders: Reviving the Ex Post Facto Clause as a Bulwark of Personal Security and Private Rights, 75 U. CIN. L. REV. 1299, 1332 (2007) (discussing the "historical punishment factor"). 
disgrace, sex offender registries cannot be analogized with these forms of punishment. ${ }^{87}$ Sex offender registries contrast the traditional punishment of shaming because, although public shame and humiliation may result from the dissemination of registry information, the resulting stigma from the registry is not an integral part of the objective regulatory scheme. ${ }^{88}$ The Court held that the purpose of registration notification is to inform the public for its own safety and the "attendant humiliation is but a collateral consequence ...."89

By limiting "traditional" forms of punishment to those dating back to the colonial period, the Smith Court rejected any arguments that analogized parole and probation to the punitive nature of sex offender registries. Thus, the Court held that registries did not constitute punishment because they did not reflect historical practices of punishment.

The Smith Court also rejected arguments that ASORA's registration requirements imposed an affirmative disability or restraint on offenders. $^{90}$ One aspect the Court evaluated under this factor was ASORA's lack of residency restriction on offenders. The Court stated that the lack of physical restraint on offenders weighed in favor of this factor supporting ASORA's regulatory purpose. ${ }^{91}$ The Court also looked to the presence of non-physical restraints, such as employment. ${ }^{92}$ Despite the reporting requirements and the public dissemination of registry information, the Court held that the Act did "not restrain activities sex offenders may pursue" and "leaves them free to change jobs or residences." 93

The Smith Court was unwilling to concede that the deterrent effect of sex offender registries could qualify the scheme as furthering the traditional aims of punishment. ${ }^{94}$ The Court feared that recognizing deterrence as a purely punitive measure would result in challenges against all civil regulatory. ${ }^{95}$ Doing so would arguably "severely undermine the Government's ability to engage in effective regulation." $" 96$

\footnotetext{
87. Smith, 538 U.S. at $98-99$.

88. Id.

89. Id. at 99 .

90. Id. at $100-02$.

91. Id. at 100 .

92. Id.

93. Id.

94. Id. at 102.

95. $I d$.

96. Id.
} 
For this reason, the Court held that the deterrence effect of ASORA does not evidence punishment. ${ }^{97}$

The Court also rejected the argument that ASORA's mechanism for assigning reporting requirement lengths based on the type of conviction - a practice that is common for most states-imposed a retributive effect. ${ }^{98}$ The Court instead upheld the application of varying reporting lengths based upon conviction because the categories reflected the risk posed, and was not punishment for the extent of the wrongdoing. ${ }^{99}$ Further, the Court explained that the broad categories and their corresponding length of reporting requirements were "reasonably related to the danger of recidivism . . . ."100 The categorical implementation of reporting length was therefore seen as consistent with ASORA's regulatory objective, rather than a retributive form of punishment. ${ }^{101}$

According to the Smith Court, the "rational relationship to a nonpunitive purpose" factor is the most significant factor in determining whether registrations are regulatory or punitive. ${ }^{102}$ The Court held that ASORA's non-punitive purpose of "public safety, which [was] advanced by alerting the public to the risk of sex offenders in their community" was legitimate. ${ }^{103}$ This reasoning reflected the Court's outlook on sex offenders as a continuing and dangerous threat to communities. In the hopes of protecting these communities, the Court ruled that public dissemination of offender information must be upheld as legitimate. ${ }^{104}$

Lastly, the Court examined whether ASORA and its requirements were excessive in relation to its regulatory purpose. ${ }^{105}$ Under this factor, the Smith Court focuses on the "dangerousness" of sex offenders "as a class" given their "substantial risk of recidivism."106 The Court based its assertions on a citation to the U.S. Dept. of Justice Bureau of Statistics stating that "[t]he risk of recidivism posed by sex offenders is 'frightening and high.",107 With this, the Court justified any punitive

\footnotetext{
97. $I d$.

98. Id.

99. Id.

100. Id.

101. Id. at $102-03$.

102. Id.

103. Id.

104. Id. at 103 .

105. Id.

106. Id.

107. Id.
} 
effect ASORA had on offenders by classifying them as a dangerous group posing a likely threat in the future. ${ }^{108}$

The Smith Court therefore held that every factor under the MendozaMartinez test weighed in favor of ASORA being a civil regulatory scheme rather than a form of criminal punishment. ${ }^{109}$ Today, the Court has yet to revisit the issue and overturn its precedent set forth in Smith.

\section{The Constitutionality of KORA}

Although the Supreme Court of the United States has not yet examined the most recent version of KORA under the United States Constitution, the Kansas Supreme Court has. Current precedent set forth by the Kansas Supreme Court's decision in State v. Petersen-Beard holds that KORA is not punitive for the purposes of applying the federal Constitution. ${ }^{110}$ In its holding, the Kansas Supreme Court made clear that the Petersen-Beard decision was to apply to all constitutional challenges as to KORA being punitive rather than a civil regulatory scheme. ${ }^{111}$

The decision to hold KORA as a legitimate civil regulatory scheme, however, did not come unanimously. In fact, in order for the Kansas Supreme Court to reach this decision, it had to overturn three decisions that were issued the same day: State v. Buser, State v. Redmond, and Doe v. Thompson. ${ }^{12}$ The story behind how this became possible is told in Justice Malone's concurring opinion in State v. Watkins. ${ }^{113}$

While Justice Malone sided with the majority in State v. Watkins, holding that KORA is not punishment, he expressed his disagreement with the Kansas Supreme Court's decision in State v. Petersen-Beard. ${ }^{114}$ Justice Malone stated that he sided with the majority in Watkins purely

\footnotetext{
108. Id.

109. Id. at 105-06.

110. State v. Petersen-Beard, 377 P.3d 1127, 1149 (Kan.), cert. denied, 137 S. Ct. 226 (2016).

111. Id. at 1130 (stating that "there exists no analytical distinction between or among the different constitutional contexts in which the question of punishment versus a civil regulatory scheme can arise.").

112. Id. at 1131. For further detail on the decisions overturned in Petersen-Beard see Doe v. Thompson, 373 P.3d 750, 771 (Kan. 2016) (holding the 2011 amendments to KORA were punitive in effect and its application to sex offenders committing crimes before July, 2011 violated the Ex Post Facto Clause); State v. Buser, 371 P.3d 886, 892 (Kan. 2016) (holding that the defendant could not be subject to KORA without violating the Ex Post Facto Clause); State v. Redmond, 371 P.3d 900, 904 (Kan. 2016) (holding that KORA was punitive and applying the KORA retroactively to sex offenders violated the Ex Post Facto Clause).

113. State v. Watkins, 401 P.3d 607, 609-11 (Kan. 2017) (Malone, J., concurring).

114. Id.
} 
for the purpose of stare decisis. ${ }^{115}$ Justice Malone, however, joined the majority opinions in State v. Buser, State v. Redmond, Doe v. Thompson, and State v. Charles holding that the 2011 KORA statutory scheme was punitive. ${ }^{116}$ Justice Malone temporarily sat on the Kansas Supreme Court as a senior judge due to a vacancy on the bench. ${ }^{117}$ Before the opinions of these cases were filed, Justice Caleb Stegall had been appointed to fill the vacancy on the Kansas Supreme Court bench. ${ }^{118}$ After his appointment, the balance of the issue concerning whether KORA was punishment shifted-thus creating the Petersen-Beard decision holding that KORA is not punishment overruling Buser, Redmond, Thompson, and Charles. ${ }^{119}$

At the time Watkins was decided, Justice Malone had stepped in again to fill a vacancy on the bench. This vacancy, however, was temporary and due to the recusal of Justice Stegall. ${ }^{120}$ Justice Stegall recused himself from Watkins because as a former Judge for the Kansas Court of Appeals, he sat on the bench that rendered the per curiam decision the Kansas Supreme Court was now reviewing. ${ }^{121}$ Therefore, recognizing that the permanent Kansas Supreme Court no longer sided with his interests, Justice Malone joined the majority in the interests of upholding stare decisis. ${ }^{122}$

\section{KORA Under the Intent-Effects Test}

The current precedent in Kansas is State v. Petersen-Beard, holding that KORA is not punitive. In State v. Petersen-Beard, the nineteenyear-old appellant Petersen-Beard sought to challenge his lifetime post release as a sex offender under KORA as cruel and unusual punishment in violation of Section 9 of the Kansas Bill of Rights and the Eighth Amendment of the United States Constitution. ${ }^{123}$ The new balance in the Court resulted in overturning the Court's prior holdings considering KORA as a form of punishment. ${ }^{124}$

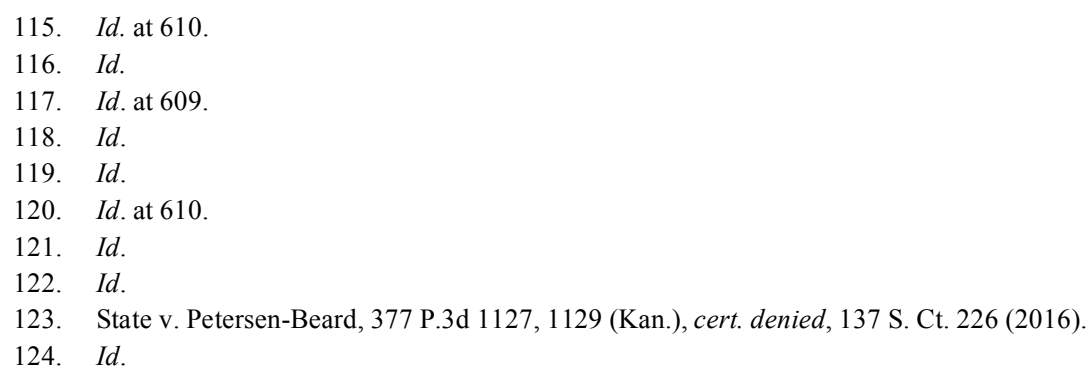


In its opinion, the Court quoted the dissent in Thompson, adopting its reasoning in toto. ${ }^{125}$ In doing so, the majority relied heavily on the Smith Court's analysis of ASORA under the "intent-effects" test.

In examining the intent of the Kansas Legislature, the Kansas Supreme Court reached the conclusion that the Legislature intended for KORA to serve as a civil regulatory scheme. ${ }^{126}$ While KORA contains no express statement of legislative intent or purpose, the Petersen-Beard Court agreed with the Kansas Supreme Court's former decision in State v. Myers $^{127}$ that the legislative history suggested that KORA was intended to serve as a public safety measure. ${ }^{128}$ The Court therefore concluded that the Kansas Legislature enacted KORA for the nonpunitive purpose of creating a civil regulatory scheme to ensure public safety. ${ }^{129}$

The Petersen-Beard Court then evaluated whether the punitive effects of KORA could override the Legislature's intent of creating a civil regulatory scheme. ${ }^{130}$ The Petersen-Beard Court followed the United States Supreme Court's decision in Smith utilizing the MendozaMartinez factors. ${ }^{131}$ In doing so, the Kansas Supreme Court followed the United States Supreme Court in Smith without any regard to the distinctions between KORA and ASORA. ${ }^{132}$

Like the Smith Court, the Petersen-Beard Court determined that every factor weighed in favor of the Mendoza-Martinez test weighing in favor of KORA being punitive. ${ }^{133}$ First, the Petersen-Beard Court determined that the effects of KORA do not resemble the historical forms of punishment; the Court did so by quoting large portions of the Smith Court's decision. ${ }^{134}$ In doing so, the Petersen-Beard Court largely adopts the Smith Court's rationale that any humiliation or public shame that comes from the dissemination of information is merely incidental to the regulatory agenda of KORA. ${ }^{135}$

\footnotetext{
125. Id. at 1131 .

126. Doe v. Thompson, 373 P.3d 750, 761-62 (2016) overruled by Petersen-Beard, 377 P.3d at 1128.

127. State v. Myers, 923 P.3d 1024, 1024 (Kan. 1996), cert. denied, 521 U.S. 1118, 1118 (1997).

128. Thompson, 373 P.3d at 761.

129. Petersen-Beard, 377 P.3d at 1130.

130. Id. at $1130-31$.

131. Id.

132. Id.

133. Id. at 1133 .

134. Id. at $1133-34$.

135. Id.
} 
Next, the Petersen-Beard Court again deferred to the Supreme Court's decision in Smith to evaluate the affirmative disability or restraint KORA puts on offenders. ${ }^{136}$ The Petersen-Beard Court noted that KORA, like ASORA, imposed no residency restrictions. ${ }^{137}$ The Court then distinguished KORA from registries with residency restrictions that have been held as unconstitutional affirmative restraint and disability. ${ }^{138}$ Further, the Petersen-Beard Court rejected any argument that the requirements of KORA such as paying a \$20 registration fee and in person reporting requirements restrict the freedom of offenders to move. ${ }^{139}$

The Petersen-Beard Court then analyzed whether KORA promotes the traditional aims of punishment. ${ }^{140}$ Citing to the Smith Court's opinion, the Petersen-Beard Court found that the fact that KORA may deter offenders from committing offenses is not enough to change the intent of the regulatory scheme into criminal punishment. ${ }^{141}$ In addressing the increased length of time that offenders are required to register under KORA in comparison to ASORA, the Petersen-Beard Court qualified the requirement as being reasonably related to the danger of recidivism posed by sex offenders. ${ }^{142}$

The Petersen-Beard Court further cites to Smith stating that KORA has a rational connection to a non-punitive purpose of promoting public safety. ${ }^{143}$ While the Petersen-Beard Court recognized that the risk of recidivism may have been overstated in Smith, it did not change its conclusion. The Court stated that this would not refute the safety interest in monitoring offender presence in the community. ${ }^{144}$

Lastly, the Petersen-Beard Court stated that KORA was not excessive in relation to its regulatory purpose because the Smith Court held states are not precluded from "making reasonable categorical judgments that certain crimes should have a particular regulatory consequence." 145 The Petersen-Beard Court added to the Smith quote by

\footnotetext{
136. Id. at $1137-38$.

137. Id.

138. Id.

139. Id. at 1138 .

140. Id. at 1139 .

141. Id.

142. Id.

143. Id. at 1139-40.

144. Id.

145. Id. at 1140 .
} 
stating that the requirements of KORA are not excessive given KORA's public safety purpose. ${ }^{146}$

While Smith might be the most current precedent, the PetersenBeard Court misapplied the Mendoza-Martinez factors in predicting how the United States Supreme Court would rule on the issue of KORA. Even under Smith precedent, the Court should distinguish KORA from ASORA and find it punitive.

\section{ANALYSIS}

KORA is easily distinguishable from ASORA and the Supreme Court of the United States should distinguish its ruling on KORA from its decision in Smith. The Court's analysis of KORA should differ under the Mendoza-Martinez factors for two main reasons: (1) empirical evidence regarding recidivism and the effect of registries has changed since its decision in Smith; and (2) KORA sweeps more broadly than the Alaska statute analyzed in Smith by including violent offenders and drug offenders under its registry. Specifically, an analysis of KORA should differ from that in Smith regarding two of the Mendoza-Martinez factors. Given KORA's distinguishable features, the Supreme Court of the United States should analyze the "rational connection to a non-punitive purpose" factor and the "excessive in relation to a regulatory purpose" factor as weighing in favor of KORA being punitive.

\section{A. Modern Empirical Evidence}

The Kansas Supreme Court misapplies the Mendoza-Martinez factors in predicting that the United States Supreme Court would hold KORA as a civil regulatory scheme instead of criminal punishment. In Petersen-Beard, the Kansas Supreme Court fails to account for empirical evidence of recidivism and the effectiveness of registries developed since Smith that the United States Supreme Court would now have at its disposal. In light of new scientific evidence, the United States Supreme Court should be evaluating KORA and its requirements with much less weight given to the public safety and prevention aspect of registries. Given that KORA's requirements are distinguishable from the requirements of ASORA by placing even more restrictions on registrants, the United States Supreme Court must weigh the punitive effects of 
KORA against a weakened argument that registries are legitimized by public safety concerns.

The Smith Court defended the punitive effects of registries stating that ASORA's requirements are "reasonably related to the danger of recidivism, and . . . consistent with the regulatory objective." ${ }^{147}$ The recidivism rate of sex offenders was described as "frightening and high" and was used to evidence their "dangerousness as a class." years since Smith, however, the Court's reference to the threatening recidivism rate of sex offenders has been referred to as "junk science." 149 Hundreds of scientific studies have sought to find the truth about sex offenders and recidivism rates. ${ }^{150}$ The studies consistently show that sex offenders have one of the lowest rates of same-crime recidivism than any other offense category. ${ }^{151}$

Even the source of the Smith Court's "frightening and high" recidivism rate citation has repudiated his statement saying it is "absolutely incorrect."152 Robert Longo, a counselor at an Oregon prison, was the source of this pseudoscientific assertion based upon no study or supporting reference. ${ }^{153}$ Longo, whose assertion appeared in a 1986 Psychology Today article, stated that his article does not reflect recent research and should not be used as a basis for public policy. ${ }^{154}$

Further, studies on recidivism in sex offenders propose that collateral consequences of sex offender registrations might actually undermine the goal of increasing public safety. ${ }^{155}$ Researchers now believe that sex offender registration laws may actually increase recidivism by exacerbating the risk factors associated with committing crime by offenders subject to the laws. ${ }^{156}$ Findings suggest that registration

\footnotetext{
147. Smith v. Doe, 538 U.S. 84, 102 (2003).

148. Id. at 103 .

149. David Feige, When Junk Science About Sex Offenders Infects the Supreme Court, N.Y. TIMES (Sept. 12, 2017), https://www.nytimes.com/2017/09/12/opinion/when-junk-science-aboutsex-offenders-infects-the-supreme-court.html.

150. Id.

151. Id.

152. Jacob Sullum, "I'm Appalled," Says Source of Phony Number Used to Justify Harsh Sex Offender Laws, REASON (Sept. 14, 2017, 9:15 AM), http://reason.com/blog/2017/09/14/im-appalledsays-source-of-pseudo-statis (referencing David Feige's documentary, UnTOUCHABLE (Blue Lawn Productions 2016)).

153. Id.

154. Id.

155. See J. J. Prescott, Portmanteau Ascendant: Post-Release Regulations and Sex Offender Recidivism, 48 CONN. L. REV. 1035, 1077-78 (2016) (discussing public safety and actual effects of sex offender registration laws).

156. Id.
} 
requirements imposed by sex offender legislation may actually destabilize sex offenders. ${ }^{157}$ Sex offenders then become more likely to report levels of depressive symptoms and hopelessness that are higher than those of the general population. ${ }^{158}$ Sex offenders experiencing these symptoms are associated with an increased risk of reoffending. ${ }^{159}$

The United States Supreme Court should not give deference to KORA serving as a safety measure protecting the public. Instead, the United States Supreme Court must weigh the onerous requirements of KORA against little, if any, evidence that KORA legitimately serves a non-punitive purpose of providing safety for the public.

In Does \#1-5 v. Snyder, the Sixth Circuit took a progressive step in reviewing sex offender registry legislation by examining interdisciplinary research to address the issue of whether the Michigan Sex Offenders Registration Act (SORA) violated the Ex Post Facto Clause of the United States Constitution. ${ }^{160}$ While evaluating SORA under the Mendoza-Martinez factors, the Sixth Circuit addressed the factor considered the most important by the Smith Court - the "rational relation to a non-punitive purpose" factor-by applying modern research on sex offenders and recidivism rates. ${ }^{161}$ The Sixth Circuit undermined SORA's non-punitive purpose by citing to research stating that "offensebased public registration has, at best, no impact on recidivism."162 The Sixth Circuit then added that some research in the record provides evidence that "laws such as SORA actually increase the risk of recidivism . ..."163 This research, paired with the fact that SORA made no individualized assessment of the dangerousness of each registrant, significantly undermined the Smith Court's decision to grant deference to the regulatory attempt of sex offender registrations. The Sixth Circuit therefore concluded that the most significant factor in determining whether a law is punitive-according to the Smith Court-actually weighs in favor of SORA constituting punishment given the lack of evidence supporting the success of registries providing public safety. ${ }^{164}$

\footnotetext{
157. Elizabeth L. Jeglic et al., The Prevalence and Correlates of Depression and Hopelessness Among Sex Offenders Subject to Community Notification and Residence Restriction Legislation, 37 AM. J. CRIM. JUST. 46, 55 (2012).

158. Id.

159. Id.

160. See Does \#1-5 v. Snyder, 834 F.3d 696, 701-06 (6th Cir. 2016), cert. denied, 138 S. Ct. 55,55 (2017).

161. Id. at $704-05$.

162. Id. at 704 .

163. Id.

164. Id. at 704-05.
} 
The Supreme Court of the United States seemingly approved of the Sixth Circuit's application of modern research of sex offenders and sex offender registries by denying certiorari. ${ }^{165}$

Like the Sixth Circuit, the Supreme Court of the United States should evaluate the legitimacy of KORA as a functioning regulatory scheme rather than punishment by applying modern research. The Court should apply the empirical evidence indicating that sex offenders do not have a high risk of recidivism and that registries are ineffective in deterring recidivism. ${ }^{166}$ This would significantly undermine any argument that KORA's requirements are justified by the promotion of public safety because sex offenders "constitute a class of criminals that [are] likely to reoffend." 167 Given that KORA imposes stricter requirements than ASORA, the Court should be able to distinguish KORA from ASORA and hold that KORA is punitive without overturning Smith v. Doe.

\section{Applying the Mendoza-Martinez Factors to KORA Using Modern \\ Research}

The Mendoza-Martinez factors most affected by modern research would be KORA's rational relation to a non-punitive purpose and KORA's excessiveness in respect to its purpose. These factors require the Court to weigh KORA's requirements that are distinguishable from those of ASORA analyzed in Smith. These distinguishable characteristics would be analyzed against evidence of sex offenders posing a low risk of recidivism and the ineffectiveness of registries lowering recidivism rates.

The most obvious distinction between KORA and ASORA is that KORA requires in-person registration at a minimum of four times a year in every county where the offender resides, maintains employment, or attends school. ${ }^{168}$ KORA registrants must not only physically report to a

\footnotetext{
165. Snyder v. Does \#1-5, 138 S. Ct. 55, 55 (2017).

166. See Prescott, supra note 155 at 1039-40 (discussing sex offender registration statutes and effect on recidivism); see also David Feige, supra note 149, at 1077-78 (explaining misconceptions about effects of sex offender registration statutes).

167. State v. Petersen-Beard, 377 P.3d 1127, 1139 (Kan.), cert. denied, 137 S. Ct. 226 (2016).

168. KAN. STAT. ANN. § 22-4905(b)(1)-(2) (West 2017) (emphasis added). Transient offenders, however, must report in person every thirty days totaling approximately three hundred and sixty dollars. $I d$. $\S 22-4905(f),(l)$. Offenders must also register in person within three days of any information change such as employment status, residency or school change, or any information listed in KAn. Stat. AnN. § 22-4907(b) (West 2017) and Kan. Stat. AnN. § 22-4905(g), (h) (West
} 2017). 
law enforcement agency, but must also pay a fee of twenty dollars each time. ${ }^{169}$ ASORA, however, did not require in-person registration and did not per se require payment upon registration. ${ }^{170}$ ASORA only required offenders to submit written verification one to four times a year, depending on the severity of the offense. ${ }^{171}$ While the burden of written registration one to four times a year was not viewed as excessive in regards to protecting the public from a then "dangerous" class of offenders, the Court's analysis should be significantly different today. The Court should now be weighing a much more onerous requirement against a weaker argument of promoting public safety in light of research providing that registration requirements do little to help promote public safety and actually facilitate reoffending. ${ }^{172}$

\section{Rational Connection to a Non-Punitive Purpose}

In using recent empirical research, the Court should conclude that KORA fails to provide a rational relation to accomplishing a nonpunitive purpose. ${ }^{173}$ Similar to that of the Sixth Circuit's decision in Does \#1-5 v. Snyder, the use of modern empirical data must negate any argument that burdensome requirements of registries are justified by "frightening and high" risks of recidivism among sex offenders. ${ }^{174}$

In Does \#1-5 v. Snyder, Michigan's sex offender registry was distinguished from ASORA because Michigan imposed residency restrictions for registrants. Although both KORA and ASORA do not impose residency restrictions, KORA can still be distinguished. Given that KORA imposes more onerous requirements such as reporting in person, longer registration terms, additional information, per se fees, notice to travel outside of the United States, annual driver's license

169. Id. $\S 22-4905(l)(2017)$. ASORA allowed the department of public safety to adopt a fee to register but required that the fees be based upon the actual costs and to be set at a level that did not discourage offenders from registering. ALASKA STAT. ANN. § 18.65.087(d)(3) (2007 \& Supp. 2014).

170. ALASKa Stat. ANN. §12.63.010(d)(1)-(2) (2007 \& Supp. 2014). ASORA allowed the department of public safety to adopt a fee to register but required that the fees be based upon the actual costs and to be set at a level that did not discourage offenders from registering. ALASKA STAT. ANN. § 18.65.087(d)(3) (2007 \& Supp. 2014).

171. Annual written verification was required for non-aggravated sex offenses and quarterly registration was required for aggravated offenses. ALASKA STAT. ANN. § 12.63.010(d)(1)-(2) (2007 \& Supp. 2014).

172. See Prescott, supra note 155 at $1039-40$.

173. See Does \#1-5 v. Snyder, 834 F.3d 696, 704 (6th Cir. 2016), cert. denied, 138 S. Ct. 55, 55 (2017).

174. Id. (citing Smith v. Doe, 538 U.S. 84, 103 (2003)). 
renewal, consideration for child custody determinations, and more burdensome penalties for violations, the Supreme Court of the United States should be able to distinguish KORA from ASORA. ${ }^{175}$ Because KORA's requirements are more burdensome than those previously analyzed by the Court, the Court should re-analyze the "rational connection to a non-punitive purpose" factor. In doing so, the Court would be compelled to use recent empirical research that severely undermines the argument used in Smith stating that registries are a legitimate way to ensure public safety. This weakened argument then must go up against a stronger argument that KORA is punitive given its harsher requirements. The weak argument that registrations serve the purpose of increasing public safety would not override the obvious punitive effects KORA's requirements impose on offenders. This factor, therefore, should be weighed in favor of KORA being punitive.

\section{Excessive in Relation to its Purpose}

In light of recent empirical evidence, the "excessive in relation to its purpose" factor should also be analyzed differently by the Supreme Court of the United States. The Smith Court was analyzing a statute that was less onerous than KORA. ${ }^{176}$ Even without modern empirical data, the Court could decide that KORA's increased requirements, such as inperson reporting, are excessive in relation to its purpose of promoting public safety. ${ }^{177}$ With modern research, however, the Supreme Court would have ample evidence to decide that KORA is excessive in relation to its purpose of public safety.

Modern empirical evidence would support weighing this factor in favor of KORA being punitive. The empirical evidence of sex offenders posing a low risk of recidivism and registries providing no assurance for public safety-and even decreasing public safety-leave no room for argument that registrations have a reasonable purpose of regulation. The Supreme Court should thus hold that KORA is punitive because its requirements are excessive and pose no relation to the purpose of public safety.

Distinguishing KORA from ASORA allows the Court to hold that KORA is punitive without overturning a decade's worth of precedent

175. Doe v. Thompson, 373 P.3d 750, 765-68 (Kan. 2016), overruled by State v. PetersenBeard, 377 P.3d 1127 (Kan. 2016).

176. Id.

177. See Smith v. Doe, 538 U.S. 84, 101 (2003). The Smith Court noted in its opinion that it based its decision, in part, on the fact that ASORA did not require in-person reporting. Id. 
under Smith. However, even if the Court ignores the new empirical evidence that make the "rational relation to a non-punitive purpose" and "excessive in relation to its purpose" factors weigh in favor of finding KORA's requirements more punitive, KORA also is distinguishable because it sweeps more broadly than ASORA.

\section{B. KORA Sweeps More Broadly}

The most distinguishable aspect of KORA from ASORA is that KORA sweeps more broadly in requiring violent offenders and drug offenders to register under the act. ${ }^{178}$ ASORA, like most states, only requires sex offenders to register. The Petersen-Beard court misapplies the excessiveness and non-punitive purpose factors of Mendoza-Martinez to KORA by neglecting to distinguish KORA from ASORA insofar as the reach KORA has over non-sex-based crimes. ${ }^{179}$

The United States Supreme Court should engage in an analysis of KORA's application to violent offenders and drug offenders under Mendoza-Martinez factors. The Court should find that the Kansas Legislature must have intended to create additional punishment as a result of certain violent and drug convictions given its broad range of offenses. Further, the Kansas Legislature provided no supportive data that these classes of offenders pose a uniquely high risk of recidivism. The Legislature also failed to include any legislative intent within the Act. ${ }^{180}$ Without this supportive data or an express intent, there is no proof the Kansas Legislature required registration to prevent recidivism and promote public safety.

1. Intent of the Legislature

The application of KORA to violent offenders and drug offenders undercuts any conclusion that the aim or effect of KORA is to protect the public. Instead, the application to certain violent and drug offenses evidences an ulterior motive to enhance the consequences of committing the offenses under the Act. The violent offender category and drug offender category reach a broad range of offenses. These broad offenses,

178. KAN. STAT. ANN. § 22-4902(a)(2), (3) (West 2017 \& Supp.).

179. While the defendant in Petersen-Beard did not challenge KORA's reach to violent and drug offenders, the Kansas Supreme Court has held that KORA was non-punitive and cited in subsequent cases regarding the constitutionality of KORA to the Petersen-Beard opinion. State v. Huey, 399 P.3d 211, 215 (Kan. 2017).

180. Thompson, 373 P.3d at 758. 
however, are comprised of an even broader range of acts required to commit the offense. The Act encompasses these various offenses and the acts required to commit them without making any connection towards their continung threat to the public's safety.

In the violent offender category, for example, KORA requires anyone convicted of involuntary manslaughter to register for fifteen years. ${ }^{181}$ Involuntary manslaughter, however, encompasses a broad range of acts in order to commit the offense. ${ }^{182}$ Acts resulting in convictions of involuntary manslaughter can range from the death of a human being in an accident caused by a driver texting while driving, to death caused during the commission of an aggravated robbery or rape. While both acts have an unfortunate consequence, it is not intuitive that both warrant the same amount of risk in recidivating. Therefore, it is not intuitive that the Kansas Legislature included violent offenders, such as those who have been convicted of involuntary manslaughter, to register under KORA for regulatory purposes.

Similarly, the drug offenses under KORA also encompass a broad range of acts to commit the offenses. Any person who is convicted of unlawfully manufacturing or attempting to manufacture a controlled substance must register under KORA. ${ }^{183}$ The Act, however, makes no effort to distinguish between those offenders manufacturing a controlled substance for personal use or for distribution to others. ${ }^{184}$ The broad scope of offenders reached under this provision is disproportionate to any public safety concern.

The Kansas Legislature's intent for KORA to serve a punitive function can also be inferred from the offenses that are not found on the registry. If the Legislature's goal was to protect the public from the offenses listed in KORA from occurring or recurring, then KORA would require offenses known to have exacerbated recidivism rates such as crimes of domestic violence. ${ }^{185}$ It is known that crimes of domestic

181. Kan. Stat. ANN. § 22-4902(e)(1)(D); KAN. Stat. ANN. § 22-4906(a)(1)(J) (West 2017 \& Supp.).

182. Involuntary manslaughter is the killing of a human being committed: (1) recklessly; (2) in commission of, or attempt to commit, or flight from a felony as defined in KAN. STAT. ANN. § 215405 (West 2012 \& Supp. 2017); (3) reckless driving as defined in Kan. STAT. ANN. § 8-1566 (West 2008); (4) driving under the influence as defined in KAN. STAT. ANN. § 8-1567 (West 2008); (4) during the commission of a lawful act in an unlawful manner.

183. KAN. STAT. ANN. § 22-4902(f)(1)(A).

184. Yancy, supra note 15 , at 35 (stating that the personal use exception to KORA was removed in 2011).

185. Domestic violence often escalates from verbal abuse, to physical violence, and even murder. $74 \%$ of all murder-suicides are committed by an intimate partner. Domestic Violence \& Abuse, U.C. DAVIS MED. CTR., https://www.ucdmc.ucdavis.edu/hr/hrdepts/asap/Documents/ 
violence represent an ongoing abusive relationship between the offender and the victim that often lead to incidents of physical harm or death. ${ }^{186}$ Therefore, domestic violence situations pose a greater risk that a violent offender will continuously reoffend and ultimately commit an offense that KORA is meant to prevent. ${ }^{187}$

Given the lack of legislative findings or published intent behind KORA, the Supreme Court of the United States should be inclined to analyze the Kansas Legislature's intent from the offenses listed in KORA. By examining the broad range of offenses encompassed in KORA including violent and drug offenses, the Court should distinguish KORA from ASORA. Alaska's Legislature professed its specific intent to protect the public from "dangerous" sex offenders directly in ASORA. ${ }^{188}$ KORA, however, gives no such reasoning or legislative finding. It cannot be reasonably inferred that the Kansas Legislature intended to create a civil regulatory scheme to protect the public when requiring sex offenders, violent offenders, and drug offenders to register under KORA.

Even if the Supreme Court of the United States were to find that the Kansas Legislature's intent in enacting KORA was to create a civil regulatory scheme, the punitive effects of KORA and its reach override this intent. The broad reach of KORA to categories other than sex offenders should change the outcome of the Mendoza-Martinez test to favor KORA being punitive. Specifically, the Mendoza-Martinez factors analyzing the rational connection to a non-punitive purpose and the excessiveness in relation to its purpose should weigh in favor of KORA being punitive.

2. Rational Connection to a Non-Punitive Purpose

Given that violent offenders and drug offenders are different classes

Domestic_Violence.pdf (last visited Apr. 14, 2018); Intimate Partner Violence, AM. PSYCHOL. Ass'N, http://www.apa.org/topics/violence/partner.aspx?item=1 (last visited Apr. 14, 2018).

186. See CDC, Prevalence and Characteristics of Sexual Violence, Stalking, and Intimate Partner Violence Victimization-National Intimate Partner and Sexual Violence Survey, United States, 2011, MORBIDITY \& MORTALITY WeEKLY REP., Sept. 5, 2014, at 1, 2, https://www.cdc.gov/ $\mathrm{mmwr} / \mathrm{pdf} / \mathrm{ss} / \mathrm{ss} 6308$.pdf.

187. The national average annual number of reported nonfatal domestic violence victimizations is $1,014,073$, and of these reported incidents, 664,518 of the cases had prior incidents of domestic abuse in the six months before the reported incident. Brian A. Reaves, Police Response to Domestic Violence, 2006-2015, U.S. DeP’T JuST. BuREAU OF Just. STAT. (May 2, 2017), http://www.bjs.gov/ index.cfm?ty $=$ pbdetail\&iid $=5907$.

188. Alaska Sex Offender Registration Act, ch. 41, § 1, 1994 Alaska Sess. Laws 41 (current version at ALASKA STAT. ANN. § 12.63.010 (West 2007 \& Supp. 2014)). 
of offenders than sex offenders, the Supreme Court of the United States would need to be presented with evidence as to whether violent offenders and drug offenders pose a significant safety threat to the public. Further, there must be a showing that the offenses specifically targeted in KORA are constructed of offenders who are more likely than other offenders not included in KORA to commit a subsequent offense.

This is highly unlikely, however, given available research about violent offenders committing the offenses listed under KORA. For example, murderers are not known for high recidivism rates. ${ }^{189}$ Violent offenders convicted of homicide have a recidivism rate of committing any type of violent crime within five years of $21.7 \% .{ }^{190}$ In contrast, offenders convicted of robbery commit violent offenses within five years at a rate of $35.8 \%$ and offenders convicted of assault have a $39.5 \%$ rate. ${ }^{191}$ Even types of offenders who would not be subject to KORA such as those convicted of burglary or larceny/motor theft have a greater likelihood of committing violent crimes within five years of their conviction. ${ }^{192}$ Therefore, offenders who are not subject to the requirements of KORA have a greater risk of committing the offenses that the Legislature is seeking to prevent by enacting KORA. ${ }^{193}$

Considering this evidence, the Supreme Court of the United States would not be able to find that KORA has a rational connection to a nonpunitive purpose. Finding that KORA had a rational connection to a non-punitive purpose would require an inference upon an inference. First, it requires the Court to speculate that offenders that commit the offense placing them on KORA will recidivate their offense. Then, it requires the Court to conclude that the risk of an offender on KORA recidivating is far greater than the risk of any given person or non-KORA offense offender to commit the crimes covered by the Act. The only way requiring registration of certain offenders under KORA would have a non-punitive purpose is if it reduced the likelihood of those crimes occurring in the future.

189. Wayne A. Logan, KNOWLedge as Power: CRiminal Registration and COMMUNity NotificAtion Laws In AmeRica 107 (Stan. U. Press, 1st ed. 2009).

190. See Recidivism of Prisoners Released in 30 States in 2005: Patterns from 2005 to 2010, U.S. DeP'T Just. BuREau OF Just. Stat. 2 tbl.2 (Dec. 2016) [hereinafter Recidivism of Prisoners], https://www.bjs.gov/content/pub/pdf/rprts05p0510_st.pdf.

191. Id.

192. Id. (showing that offenders convicted of burglary have a violent offense recidivism rate of $30.1 \%$ and that offenders convicted of larceny/motor vehicle theft have a violent offense recidivism rate of $29.4 \%$ ).

193. See KAn. Stat. AnN. § 22-4902(e)(1)(A)-(I) (West 2017 \& Supp.). 
While the Smith Court had the Alaska Legislature's findings that sex offenders posed a high risk of recommitting their sex offenses, the United States Supreme Court would have no such data provided by KORA. ${ }^{194}$ In fact, the available data suggests the opposite for violent offenders - those who commit violent offenses are less likely than others to commit a violent offense listed under KORA. ${ }^{195}$ If subjecting KORA offenders to registration will not actually promote public safety by way of preventing crime from occurring in the future, then KORA and its reach to violent offenders and drug offenders cannot be said to have a rational connection to a non-punitive purpose. This factor-the Court in Smith thought to be the most important factor-should weigh in favor of KORA being punitive.

\section{Excessive in Relation to its Regulatory Purpose}

In examining whether KORA and its application to violent offenders and drug offenders is excessive in respect to its purpose, the Supreme Court of the United States should distinguish KORA from its decision in Smith. In doing so, the Court should hold that KORA's application to a broader range of offenders is excessive. The question for the United States Supreme Court under this factor would be whether the regulatory scheme of requiring violent offenders and drug offenders to register is reasonable in light of the non-punitive objective - presumably preventing violent and drug crimes. ${ }^{196}$

The Kansas Supreme Court in Petersen-Beard misapplied this factor when applying precedent from Smith. The Petersen-Beard Court assumed that because the Smith Court found the regulation of sex offenders reasonable, then the regulation of any other crime thought to be dangerous was reasonable. ${ }^{197}$ In its opinion, the Smith Court specifically stated that "[t]he Ex Post Facto Clause does not preclude a State from making reasonable categorical judgments that conviction of specified

\footnotetext{
194. The Alaska Legislature wrote into ASORA that sex offenders posed a "high risk of reoffending" and thus regulating these offenders was a way for the government to protect the public since these offenders were the class of persons likely to commit sex offenses in the future. Smith v. Doe, 538 U.S. 84, 93 (2016) (quoting Alaska Sex Offender Registration Act, ch. 41, § 1, 1994 Alaska Sess. Laws 41 (current version at AlASKA STAT. ANN. § 12.63 .010 (West 2007 \& Supp. 2014))).

195. See Recidivism of Prisoners, supra note 190, at 2 tbl.2.

196. See Smith v. Doe, 538 U.S. 84, 105 (2002) (stating that "[t]he question is whether the regulatory means chosen are reasonable in light of the nonpunitive objective").

197. See State v. Petersen-Beard, 377 P.3d 1127, 1140 (Kan.), cert. denied, 137 S. Ct. 226 (2016).
} 
crimes should entail particular regulatory consequences."198 The Smith Court's only concern, however, was the categorical application of a regulatory statute reaching sex offenders. ${ }^{199}$ The Smith Court concluded that the categorical judgment concerning sex offenders was reasonable based on the empirical evidence it was provided. This evidence stated that " $[w]$ hen convicted sex offenders reenter society, they are much more likely than any other type of offender to be rearrested for a new rape or sexual assault." ${ }^{200}$ Based on this data, the Smith Court decided that the categorical judgment of sex offenders was reasonable to protect the public from sex offenses. ${ }^{201}$

The United States Supreme Court's analysis of whether KORA makes reasonable categorical judgments should require a separate analysis given that KORA sweeps more broadly than just sex offenders. This would require the Court to examine whether all violent offenders and all drug offenders pose the same risk of recidivism and same safety threat to the public. Unlike in Smith, the Court would have no legislative evidence to support that KORA's categorical judgments are reasonable. The Kansas Legislature's lack of a careful determination of recidivism is revealed by the vast array of "targeted" offenses included in KORA.

Not only should the Court require that Kansas provide some sort of empirical evidence that violent offenders and drug offenders pose a greater risk, but that the more onerous requirements of KORA - such as in-person reporting requirements - are reasonable to achieve public safety. While there is a lack of empirical data concerning the effect of registries on violent offenders and drug offenders, the same framework used to evaluate the effect of registration on sex offenders can be loosely applied to make a hypothesis on violent and drug offenders under registries. ${ }^{202}$ Findings suggest that registration requirements imposed by

\footnotetext{
198. Smith, 538 U.S. at 103 (emphasis added).

199. See id.

200. Id. (internal citations omitted). This data, however, has since proven to be incorrect and has been recanted. Longo, whose assertion appeared in a 1986 Psychology Today article, stated that his article does not reflect recent research and should not be used as a basis for public policy. Sullum, supra note 152 (referencing David Feige's documentary, "Untouchable"). He also stated that the journal is not a scientific journal and questioned the Court's practice of citing to a "popular psychology magazine." Id. The Court relied on Longo's article as it appeared in the Department of Justice manual written by a psychologist by the name of Barbara Schwartz. Id. Schwartz now admits that she "couldn't find any" information on sex offender recidivism rates and that she "basically .. . just made-up a model." Id. She now refers to her work in the 1980s as deliberate indifference - a series of guesses that make no sense. Id.

201. See Smith, 538 U.S. at 104.

202. See Prescott, supra note 155 at 1039-40 (concluding that sex offender registries may undermine the goal of increasing public safety by exacerbating risk factors associated with destabilizing sex offenders making recidivism more likely).
} 
sex offender legislation may in fact be destabilizing to sex offenders. ${ }^{203}$ Registration is de-stabilizing to sex offenders because the likelihood of detection of crime increases. ${ }^{204}$ While this makes returning to crime less attractive for sex offenders, it also reduces their quality of life. This is because collateral consequences of registering as a sex offender are associated with "increasing poverty, loneliness, idleness, and disconnectedness . . .."205 As a result, the reduction in quality of life makes reoffending become less costly to offenders and makes recidivism become more likely. ${ }^{206}$ This research suggests that the requirements of sex offender registrations are so excessive that instead of working to fulfill the purpose of public safety, they actually works against the purpose of public safety. ${ }^{207}$

By loosely applying this framework to violent offenders and drug offenders, it is reasonable to predict that registries on this class of offenders would yield the same results. It is reasonable to conclude that drug offenders and violent offenders would also experience a decrease in quality of life. Drug offenders and violent offenders would experience the ostracism of being labeled a criminal. Offenders would experience the collateral consequences as a result of this stigma. The decrease in quality of life and continued ostracism would make reoffending less costly and may provide more benefits, such as money, that would otherwise not be available. The result, then, is the same-the consequences of being subjected to registry requirements actually exacerbate the risk factors associated with committing crime. Therefore, the data would suggest that subjecting violent offenders and drug offenders to registration is excessive to the point of undermining the government's purpose of promoting public safety.

The "excessive in relation to a regulatory purpose" factor of the Mendoza-Martinez test weighs in favor of KORA being punishment. KORA's broad reach of offenses and categorical application without any sort of risk assessment actually increases the commission of these offenses. KORA applies to offenders who, without experiencing a decrease in quality of life due to the consequences of registration, may have had little to no risk of reoffending. Therefore, it cannot be said that requiring broad categories of violent offenders and drug offenders to register under KORA has a rational relation to achieving the purpose of

203. Jeglic et al., supra note 157 , at 55 .

204. Prescott, supra note 155, at 1067.

205. Id.

206. Id. at 1063

207. Id. at 1078 . 
public safety. KORA, then, can reasonably be regarded as excessive, and therefore, this factor weighs in favor of KORA being punitive.

The Supreme Court of the United States should distinguish KORA from its decision in Smith regarding ASORA. Most notably, the Court's decision should differ from that in Smith on two Mendoza-Martinez factors: the "rational connection to a non-punitive purpose" factor and the "excessive in relation to a regulatory purpose" factor. The Court's analysis of these factors should differ for two main reasons: (1) empirical evidence regarding recidivism and the effect of registries has changed since its decision in Smith; and (2) KORA sweeps more broadly than the Alaska statute analyzed in Smith by including violent offenders and drug offenders under its registry. Given these distinguishable factors of KORA, the Supreme Court of the United States should analyze the "rational connection to a non-punitive purpose" factor and the "excessive in relation to a regulatory purpose" factor to weigh in favor of KORA being punitive.

\section{CONCLUSION}

The Kansas Offender Registry Act crosses the line between civil and punitive legislation under the Supreme Court's analysis in Smith. When analyzed under the Mendoza-Martinez factors, KORA cannot be justified as a civil regulatory scheme. Although it does not impose traditional "colonial" punishment, KORA imposes punishment in the form of restricting an offender's right to freely live and work in our society. This restriction upon an offender's liberty imposes a hardship that promotes the traditional aims of punishment.

More research is needed to determine whether the goal of this "regulatory scheme" is rationally related to a non-punitive purpose. Data available today suggests it is not. The broad scope of KORA, which applies not only to sex offenders, but to violent and drug offenders, is excessive with respect to the stated purpose of the legislation, which is presumably to protect the public from offenders who have a uniquely high rate of recidivism.

If the Supreme Court reviews KORA, it will likely distinguish KORA from the sex offender registry formerly reviewed in Smith and find it unconstitutional. Applying the Mendoza-Martinez factors to KORA in light of more recent empirical data may shape the future of our criminal justice system. Defendants, like Joe from the beginning hypothetical, may finally get the recourse they have needed. 